\title{
Body weight of dairy heifers is positively associated with reproduction and stayability
}

\author{
R. C. Handcock, ${ }^{1 *}$ ๑ N. Lopez-Villalobos, ${ }^{1}$ ৫ L. R. McNaughton, ${ }^{2}$ P. J. Back, ${ }^{1}$ G. R. Edwards, ${ }^{3}$ \\ and R. E. Hickson ${ }^{1}$ \\ ${ }^{1}$ School of Agriculture and Environment, Massey University, Palmerston North 4442, New Zealand \\ ${ }^{2}$ Livestock Improvement Corporation, Hamilton 3240, New Zealand \\ ${ }^{3}$ Faculty of Agriculture and Life Sciences, Lincoln University, Lincoln 7647, Christchurch, New Zealand
}

\section{ABSTRACT}

This study investigated the relationships between body weight (BW) and stayability, and BW and calving pattern, of 189,936 New Zealand dairy heifers. Heifers were classified into 5 breed groups: HolsteinFriesian (F), Holstein-Friesian crossbred (FX), Jersey $(\mathrm{J})$, Jersey crossbred (JX), and Holstein-Friesian $\times$ Jersey crossbred (FJ). Body weight was predicted using Legendre polynomials at 6,12, and 15 mo of age, and we analyzed their relationships with stayability, calving rate, and re-calving rate over the first 3 calvings. Approximately $92 \%$ of heifers calved for the first time at age $2 \mathrm{yr}, 76 \%$ a second time at $3 \mathrm{yr}$, and $61 \%$ a third time at 4 yr. Heifers that were heavier were more likely to remain in the herd for first, second, and third calving compared with heifers that were lighter. Furthermore, we found positive curvilinear relationships between prebreeding BW and reproductive performance of dairy heifers. Heifers that were heavier at 6,12 , and 15 mo were more likely to calve early for first calving compared with heifers that were lighter, regardless of breed group. In addition, we found a large range in BW where the probability of calving or re-calving early was high. For example, FJ heifers that were between 255 and 396 $\mathrm{kg}$ at 15 mo of age had 21-d calving and re-calving rates above 75 and $70 \%$, respectively. For second and third lactations, however, heifer pre-breeding BW showed only small effects on the 21-d calving and recalving rates. For heifers that were at the heaviest end of the BW range in the current study, slight declines in stayability and reproductive performance occurred, compared with heifers in the mid-range of BW. Consequently, for heifers that were above average in BW, the benefit of increasing BW before first breeding would be small and might even result in slight declines in

Received September 4, 2019.

Accepted December 30, 2019.

*Corresponding author: R.C.Handcock@massey.ac.nz stayability and reproductive performance. For heifers that were below average in BW, considerable beneficial effects on stayability and reproductive performance are predicted as a result of improving rearing practices to produce heavier heifers throughout the pre-breeding rearing phase.

Key words: weight, heifer, survival, reproduction

\section{INTRODUCTION}

Herds that have greater cow survival rates have a greater proportion of mature, high-producing cows and a lower proportion of replacement heifers needing to be reared, compared with herds that have low cow survival rates (Pritchard et al., 2013). Recording fates of dairy cows in New Zealand is voluntary, and large proportions of cows show missing dates or reasons for removal, or both $(43 \% ; \mathrm{n}=6,988,011$ out of $16,399,396$ considered; Kerslake et al., 2018). A measure of cow survival that does not require recording of cull data is stayability (STAY); Hudson and Van Vleck (1981) defined STAY as the probability of an animal surviving to a specific age given that they had the opportunity to reach that age.

Pritchard et al. (2013) and Brickell et al. (2009b) reported that 13.7 and $14.5 \%$, respectively, of HolsteinFriesian heifers in the United Kingdom did not survive to first calving. Meier et al. (2017) reported that the loss of Holstein-Friesian heifers from collection (approx. $9 \mathrm{~d}$ of age) to $17 \mathrm{mo}$ of age for a New Zealand research herd with divergent genetic fertility was 4.8 and $9.8 \%$ for heifers that were of high $(\mathrm{n}=289)$ or low $(\mathrm{n}=276)$ genetic merit for fertility, respectively. The heritability of heifer survival was low (0.01), suggesting that environmental factors influenced heifers' survival to $25 \mathrm{mo}$ of age to a greater extent than genetics (Pritchard et al., 2013). A suggestion to improve heifers' survival was to improve the management of heifers (Pritchard et al., 2013), which may result in an improvement in heifer BW. A greater number of the heaviest Holstein-Friesian 
heifers $(\geq 343 \mathrm{~kg}$ ) were present at the beginning of first (93\% vs. $82 \%$ ) and second ( $76 \%$ vs. $62 \%$ ) lactations compared with the lightest $(\leq 290 \mathrm{~kg}$ ) heifers (Archbold et al., 2012), emphasizing the survival benefits of having Holstein-Friesian heifers heavier at breeding. In addition, the data from Pritchard et al. (2013), Brickell et al. (2009b), and Archbold et al. (2012) indicate that survival studies that use first calving as the baseline may not capture the wastage that occurs when heifers don't survive to first calving (Brickell and Wathes, 2011).

Poor reproductive performance has been shown to be the main cause of cow removal from herds in New Zealand: $35 \%$ of cows culled were for reproductive reasons (Kerslake et al., 2018). The success of a seasonal pasture-based dairy system is largely dependent on matching maximum animal demand with peak pasture growth (Roche et al., 2007). To achieve this, the main goal in a seasonal pasture-based system is to get as many cows pregnant as quickly as possible after a fixed calendar date (planned start of breeding or mating, PSM), to achieve a compact calving pattern the next year (Roche et al., 2007). The planned start of calving (PSC) date is assumed to be $282 \mathrm{~d}$ after PSM, based on the average gestation length of dairy cattle (Haile-Mariam and Pryce, 2019). The percentage of cows that conceive within $42 \mathrm{~d}$ ( 6 weeks) of PSM (6-wk pregnancy rate) is used as the benchmark of reproductive performance in seasonal dairy systems $(\mathrm{Xu}$ and Burton, 2003). The New Zealand national average 6-wk pregnancy rate for the 2017-2018 spring calving season was $66 \%, 12 \%$ below the industry target (Livestock Improvement Corporation and DairyNZ, 2018). Pregnancy rates can only be determined reliably when early-aged pregnancy diagnosis are performed (Hemming et al., 2018). In large-scale analyses, where early-aged pregnancy diagnosis is not performed (or recorded) for all animals, the percentage of cows calving within 21 or $42 \mathrm{~d}$ of PSC can be estimated and used to compare reproductive performance.

First-calving heifers tend to be bred earlier than the main herd, to allow for all cows to be cycling by PSM, due to prolonged periods of anestrous of firstcalving heifers compared with mature cows (Fonseca et al., 1983; McDougall et al., 1995). To account for these differences in PSM, industry targets for calving rates are $75 \%$ of first-calvers calved within $21 \mathrm{~d}$ of PSC and $60 \%$ of the whole herd calved within $21 \mathrm{~d}$ of PSC (DairyNZ, 2018). A greater proportion of replacement heifers that calved early in their first lactation also calved early in their second lactation, compared with heifers that calved later in their first lactation (Pryce et al., 2007). This relationship with earliness of calving in subsequent years emphasizes the importance of early-calving heifers, as they are likely to become early-calving cows. Having cows that calve early in the calving period ensures a longer lactation, which has been shown to have marked effects on production and profitability (McDougall and Compton, 2006). Furthermore, in an Irish study, more Holstein-Friesian heifers that were heavier at first breeding (291 to $316 \mathrm{~kg}$ ) calved earlier than heifers that were lighter $(\leq 290 \mathrm{~kg})$ at breeding (Archbold et al., 2012); therefore, it would be advantageous to have heifers heavier before their first breeding period.

The major dairy breeds in New Zealand are HolsteinFriesian $(33.4 \%)$, Jersey $(9.2 \%)$, and Holstein-Friesian $\times$ Jersey crossbred $(\mathbf{F} \times \mathbf{J} ; 47.8 \%$; Livestock Improvement Corporation and DairyNZ, 2018), with a large range of Holstein-Friesian and Jersey breed proportions in the $\mathrm{F} \times \mathrm{J}$ breed. Jersey heifers were lighter than $\mathrm{F} \times \mathrm{J}$ and Holstein-Friesian heifers (Handcock et al., 2018) and had better reproductive performance than Holstein-Friesian heifers during first and second lactations (Grosshans et al., 1997; Xu and Burton, 2003). The growth pattern of Holstein-Friesian, Jersey, and $\mathrm{F} \times \mathrm{J}$ heifers differed throughout the rearing phase (Handcock et al., 2018), suggesting a breed-specific optimum BW to yield maximum milk production and reproductive performance.

A previous study, based on the same heifers as the current study, showed that heifers that were heavier pre-breeding produced more milk in first lactation and accumulated over 3 parities, compared with heifers that were lighter (Handcock et al., 2019). Minimal studies have quantified the survival or reproductive benefits of heavier heifers. In addition, no studies have compared the effect of heifer BW on stayability or reproduction among various breeds. The aims of the current study were to explore the relationships between pre-breeding BW and stayability and between pre-breeding BW and 2 measures of reproductive performance of New Zealand dairy heifers of varying breeds.

\section{MATERIALS AND METHODS}

\section{Initial Data Set}

Body weight records from 189,936 spring-born New Zealand dairy heifers born between the 2006 and 2013 spring-calving dairy seasons were extracted from the Livestock Improvement Corporation (LIC) internal national dairy database (Handcock et al., 2018). Heifers were included if they had at least 2 BW records between birth and $12 \mathrm{mo}$ of age and at least $2 \mathrm{BW}$ records between 13 mo of age and first calving at 2 yr of age (Handcock et al., 2018). Growth curves were generated for each heifer using random regression of a fourth- 
Table 1. Number of Holstein-Friesian (F), Holstein-Friesian crossbred (FX), Holstein-Friesian $\times$ Jersey crossbred (FJ), Jersey crossbred (JX), and Jersey $(\mathrm{J})$ heifers born between spring 2006 and spring 2013 (reared) with recorded calving dates between spring 2008 and spring 2017

\begin{tabular}{llrrr}
\hline Breed group & Breed composition & Reared & C2yo & C3yo $^{1}$ \\
\hline F & $\mathrm{F} \geq 14 / 16$ & 48,026 & 44,351 & 35,600 \\
FX & $10 / 16 \leq \mathrm{F} \leq 13 / 16$ & 62,400 & 57,883 & 47,742 \\
FJ & $\mathrm{F}<10 / 16$ and J $<10 / 16$ & 42,885 & 39,517 & 32,909 \\
JX & $10 / 16 \leq \mathrm{J} \leq 13 / 16$ & 24,218 & 22,187 & 38,662 \\
J & $\mathrm{J} \geq 14 / 16$ & 12,407 & 11,204 & 27,141 \\
Total & - & 189,936 & 175,090 & 15,118 \\
Percentage & - & 100 & 92.2 & 143,696 \\
\hline
\end{tabular}

${ }^{1} \mathrm{C} 2 \mathrm{yo}=$ first calving as a 2-yr-old, C3yo $=$ second calving as a 3 -yr-old, C4yo $=$ third calving as a 4-yr-old.

order Legendre polynomial in ASReml (Gilmour et al., 2015), as described by Handcock et al. (2018). Using the regression coefficients from the growth curves, BW were predicted for each heifer at 6,12 , and 15 mo of age using SAS version 9.4 (SAS Institute Inc., Cary, NC).

Based on pedigree information, breed composition (expressed in 16ths) was used to classify heifers into 1 of 5 breed groups: Holstein-Friesian $(\mathbf{F})$, HolsteinFriesian crossbred $(\mathbf{F X})$, Jersey $(\mathbf{J})$, Jersey crossbred $(\mathbf{J X})$, and Holstein-Friesian-Jersey crossbred $(\mathbf{F J})$. The criteria used to classify breed groups are outlined in Table 1. All heifers in the data set were $16 / 16$ pedigree recorded and were no more than $2 / 16$ of any breed other than Holstein-Friesian or Jersey.

\section{Stayability Data Set}

Calving dates between Jun. 1, 2008, and Dec. 31, 2017, for the 189,936 heifers were extracted from the LIC internal national dairy database as described by Handcock et al. (2019); these heifers were termed "heifers that were reared." Stayability was measured to first calving as a 2-yr-old (C2yo), second calving as a 3-yrold (C3yo), and third calving as a 4-yr-old (C4yo). For $\mathrm{C} 2 \mathrm{yo}$, heifers that calved between June and December at approximately 2 yr of age were considered successful and coded 1 ( $\mathrm{n}=175,142$; Table 1$)$; heifers that did not meet these criteria were considered unsuccessful and coded 0 for C2yo, C3yo, and C4yo $(\mathrm{n}=14,794)$. From the 175,142 heifers that calved as 2-yr-olds, heifers that had a second calving at 3 yr of age were coded 1 for C3yo ( $\mathrm{n}=143,696$; Table 1$)$, and those that did not were coded 0 for C3yo and C4yo $(\mathrm{n}=31,446)$. This process was repeated one further time for third calving at $4 \mathrm{yr}$ of age, with 116,234 heifers coded 1 (Table 1) and 27,462 heifers coded 0 for C4yo.

\section{Calving and Re-Calving Rate Data Set}

For the purposes of this study, the proportion of animals that calved within $21 \mathrm{~d}$ of PSC, provided they calved that year, will be considered as calving rate (C21), and the proportion of animals that calved within $21 \mathrm{~d}$, provided they calved the year prior, will be considered as re-calving rate ( $\mathbf{R C 2 1})$.

To generate the calving rate data set, PSM and PSC dates were extracted from the LIC internal national dairy database for each herd and year combination from which the heifers were located. The PSM and PSC dates for heifers that had a first calving (C2yo; $\mathrm{n}=$ $175,142$ ), second calving (C3yo; $n=143,696)$, and third calving ( $\mathrm{C} 4 y o ; n=116,234)$ were considered as 3 separate data sets. Heifers from herds with no PSC date for a herd-year were removed from the data sets (C2yo $n$ $=9,737$, C3yo $\mathrm{n}=11,145$, and C4yo $\mathrm{n}=11,542)$. The interval from PSC to calving was calculated for each heifer, and heifers that calved between $47 \mathrm{~d}$ before PSC and $142 \mathrm{~d}$ after PSC for each year were selected for the analysis of C21 (Brownlie et al., 2014). Heifers outside this criteria for each calving were removed from the data set for that calving. A heifer was coded 1 for C21 if she calved within $21 \mathrm{~d}$ of PSC and 0 if she calved later than $21 \mathrm{~d}$. Thus, 165,302 records were retained for first calving (C21_2yo), 132,482 records for second calving (C21_3yo), and 104,649 records for third calving (C21_4yo).

For first-calving heifers, re-calving rate was estimated from heifers that were reared. For example, RC21 for first-calvers (RC21_2yo) was measured as the proportion that calved within $21 \mathrm{~d}$ of PSC, provided they were reared. For second-calvers, RC21_3yo was the proportion of heifers that calved within $21 \mathrm{~d}$ of PSC, provided they calved as 2-yr-olds, and likewise for third-calving re-calving rate (RC21_4yo).

To create the data set for RC21, heifers that did not have a recorded first calving date at age 2 yr from the STAY data set $(\mathrm{n}=14,794)$ but were from herds with PSC information $(\mathrm{n}=13,161)$ were coded 0 for RC21_2yo. Likewise, heifers that did not have a recorded second calving date as 3 -yr-olds $(\mathrm{n}=31,446)$ but were from herds with PSC information ( $\mathrm{n}=$ 28,868) were coded 0 for RC21_3yo. Finally, heifers that did not have a recorded third calving date at age $4 \mathrm{yr}(\mathrm{n}=27,462)$ but were from herds with PSC in- 
Table 2. Least squares means ( \pm SEM) for stayability, 21-d calving rate [calved within $21 \mathrm{~d}$ of planned start of calving (PSC), provided they calved; C21] and 21-d re-calving rate (calved within $21 \mathrm{~d}$ of PSC, provided they calved the year prior; RC21) for Holstein-Friesian (F), HolsteinFriesian crossbred (FX), Holstein-Friesian $\times$ Jersey crossbred (FJ), Jersey crossbred (JX), and Jersey $(\mathrm{J})$ cows

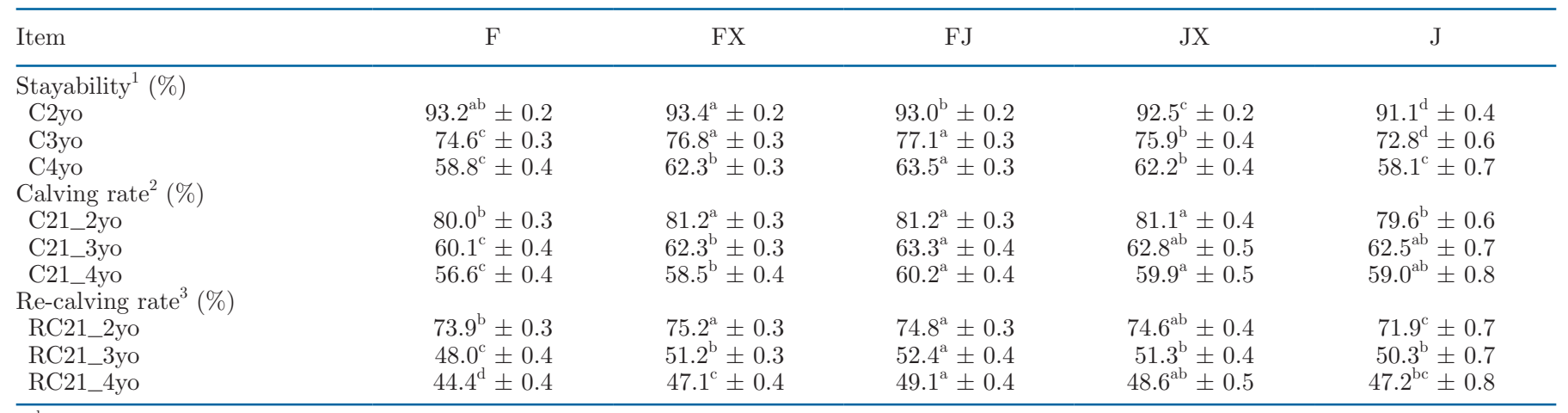

${ }^{\mathrm{a}-\mathrm{d}}$ Means within row with different superscripts differ between breed groups $(P<0.05)$.

${ }^{1} \mathrm{C} 2 \mathrm{yo}=$ first calving as a 2-yr-old, C3yo $=$ second calving as a 3 -yr-old, C4yo $=$ third calving as a 4 -yr-old.

${ }^{2} \mathrm{C} 21 \_2 \mathrm{yo}, \mathrm{C} 21 \_3 y o$, C21_4yo = heifers that calved within $21 \mathrm{~d}$ of PSC for first, second, and third calving, respectively.

${ }^{3} \mathrm{RC} 21 \_2 \mathrm{yo}, \mathrm{RC} 21 \_3 y o, \mathrm{RC} 21 \_4$ yo $=$ heifers that re-calved within $21 \mathrm{~d}$ of PSC, provided they were reared, for first calvers, second calvers, and third calvers, respectively.

formation $(\mathrm{n}=24,529)$ were coded 0 for RC21_4yo. In this way, 178,463 records were retained for RC21_2yo, 161,350 records for RC21_3yo, and 129,178 records for RC21_4yo.

\section{Statistical Analysis}

Data were analyzed using SAS version 9.4 (SAS Institute Inc.). Least squares means of dependent variables for each breed group were obtained using mixed models based on a binomial distribution and using a logittransformation. The models included the fixed effect of breed group (F, FX, FJ, JX, J), the covariate deviation from median date of birth (within herd-year), and the random effect of herd-year. Herd-year was defined as the herd and year at which the heifer started her first lactation. For second- and third-calving and re-calving rates, the deviation from median date of calving the year prior was included in the models.

The effects of BW on STAY, C21, and RC21 were analyzed using the same mixed models as above, with the addition of the linear and quadratic effects of $\mathrm{BW}$ within breed group. The STAY, C21, and RC21, as influenced by BW for each breed group, was estimated using the ESTIMATE statement within the GLIMMIX procedure of SAS in 1-kg increments of BW, using mean values for deviation from median date of birth and date of calving.

\section{RESULTS}

\section{Breed Groups}

Approximately $92 \%$ of heifers that were reared calved for the first time as 2-yr-olds, $76 \%$ a second time as
3 -yr-olds, and $61 \%$ a third time as 4-yr-olds (Table 1 ). Breed groups differed in performance, and crossbreeds (FX, FJ, and JX) generally had better performance than straight breeds (F and J; Table 2).

\section{Stayability}

Within breed group, heifers that were heavier were more likely to remain in the herd for first, second, and third calving, compared with heifers that were lighter. For 15-mo-old FJ heifers, the mean STAY to first calving was less than $90 \%$ at BW below $255 \mathrm{~kg}$ and above $415 \mathrm{~kg}$ (Figure 1 and Table 3). Likewise, the mean STAY to second calving was less than $75 \%$ at BW below $273 \mathrm{~kg}$ and above $411 \mathrm{~kg}$, and at BW below 263 $\mathrm{kg}$ and above $402 \mathrm{~kg}$, mean STAY to third calving was less than $60 \%$ (Figure 1 and Table 3), demonstrating a large range in 15-mo BW for which STAY was high.

Similar results were found for other breed groups studied (Table 3) and for heifers at 6 and 12 mo of age (Supplemental Tables S1 and S2, https://doi.org/10 .3168/jds.2019-17545). For F heifers, 15-mo BW above $274 \mathrm{~kg}$ resulted in STAY to first calving above 90\%, and there was no upper limit within the BW range studied for which STAY was less than 90\% (Table 3).

\section{Calving and Re-Calving Rates}

Similar to the results for stayability, we discovered positive curvilinear relationships between pre-breeding BW and $\mathrm{C} 21$ and RC21 of dairy heifers, displayed graphically in Figure 2 for $\mathrm{C} 21$ and Figure 3 for RC21 for FJ heifers at 15 mo of age. A large range in 15-mo BW existed for which the probability of calving or re- 


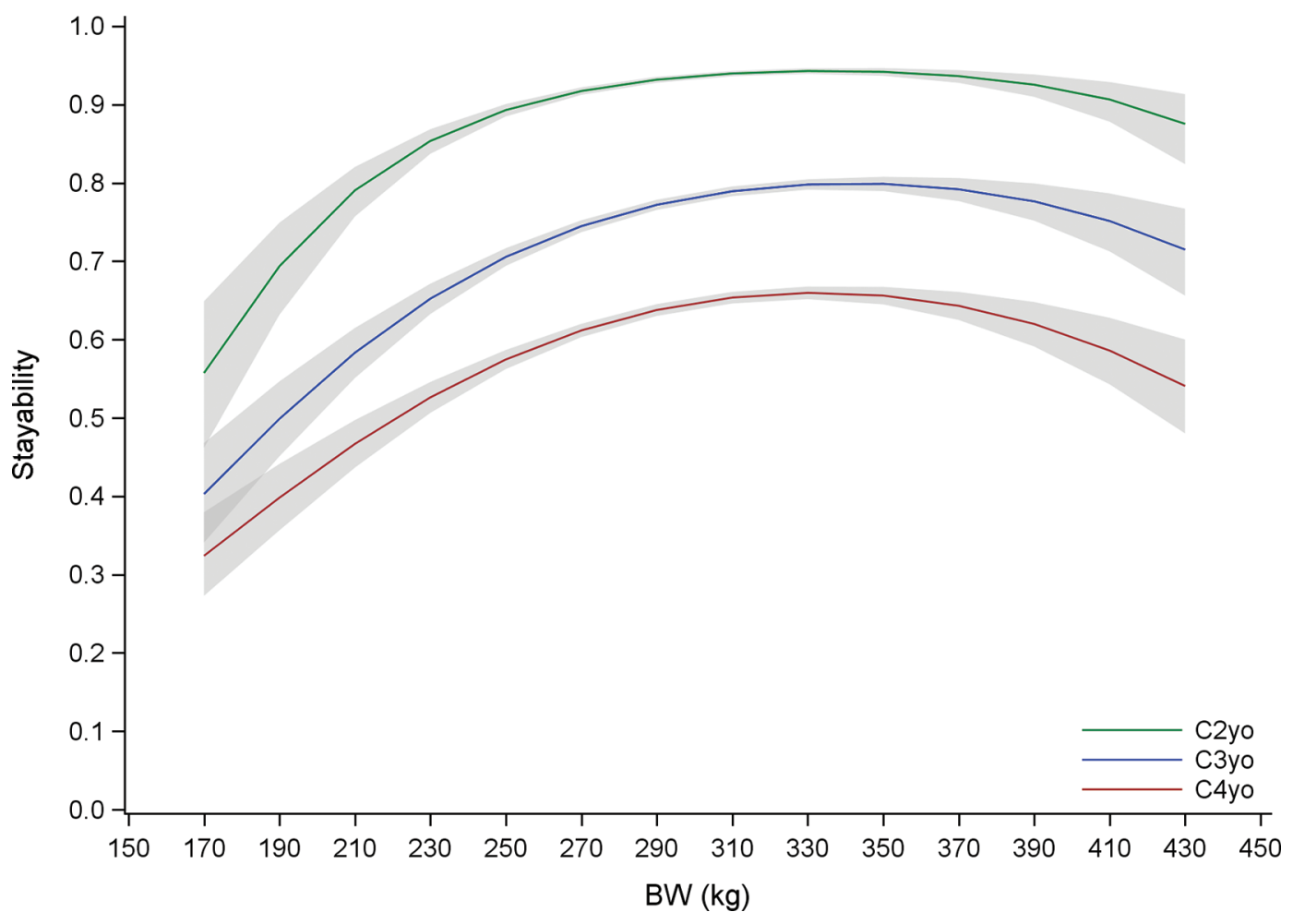

Figure 1. Relationship between BW at 15 mo of age and stayability of Holstein-Friesian $\times$ Jersey crossbred (FJ) heifers that calved as 2-yrolds (C2yo), 3-yr-olds (C3yo), or 4-yr-olds (C4yo), provided they were reared. Shaded areas indicate 95\% CI.

calving early for first calving was high (Table 3). For second and third lactations however, only small effects of heifer pre-breeding BW on the earliness of calving (Table 3) were found. For heifers at the heaviest end of the BW range in the current study, a slight decline in reproductive performance occurred, compared with heifers in the mid-range of BW (Figures 3 and 4). Similar results were found for other breed groups studied

Table 3. The range of 15-mo BW (kg) where stayability, 21-d calving rate [calved within $21 \mathrm{~d}$ of planned start of calving (PSC), provided they calved; C21], and 21-d re-calving rate (calved within $21 \mathrm{~d}$ of PSC, provided they calved the year prior; RC21) were above the threshold for Holstein-Friesian (F), Holstein-Friesian crossbred (FX), Holstein-Friesian $\times$ Jersey crossbred (FJ), Jersey crossbred (JX), and Jersey (J) cows

\begin{tabular}{|c|c|c|c|c|c|c|}
\hline $\begin{array}{l}\text { Parameter } \\
\text { and age }\end{array}$ & $\begin{array}{c}\text { Above } \\
\text { threshold of }\end{array}$ & $\mathrm{F}$ & FX & FJ & JX & $\mathrm{J}$ \\
\hline \multicolumn{7}{|l|}{ Stayability $^{1}$} \\
\hline $\mathrm{C} 2 \mathrm{yo}$ & $90 \%$ & $\geq 274$ & $263-421$ & $255-415$ & $248-385$ & $238-345$ \\
\hline C4yo & $60 \%$ & $314-390$ & $275-398$ & $263-402$ & $259-366$ & 274-314 \\
\hline \multicolumn{7}{|c|}{ Calving rate ${ }^{2}$} \\
\hline C21_2yо & $75 \%$ & $263-451$ & $\geq 234$ & $231-411$ & $201-414$ & 179-363 \\
\hline RC21_2уо & $70 \%$ & $283-439$ & $263-432$ & $255-396$ & $240-379$ & $228-332$ \\
\hline RC21_3уо & $50 \%$ & $324-395$ & $\geq 249$ & $252-403$ & $246-387$ & $\geq 232$ \\
\hline RC21_4yo & $50 \%$ & ${ }^{4}$ & $304-340$ & $253-376$ & $256-349$ & $242-289$ \\
\hline
\end{tabular}

${ }^{1} \mathrm{C} 2 \mathrm{yo}=$ first calving as a 2-yr-old, C3yo $=$ second calving as a 3 -yr-old, and C4yo $=$ third calving as a 4-yr-old.

${ }^{2} \mathrm{C} 21 \_2$ yo, C21_3yo, C21_4yo = heifers that calved within $21 \mathrm{~d}$ of PSC for first, second, and third calving, respectively.

${ }^{3} \mathrm{NA}=\mathrm{C} 21$ was not below the threshold of $60 \%$ within the BW range studied.

${ }^{4} \mathrm{No}$ BW at which the probability of $\mathrm{C} 21$ or RC21 was above the threshold of $60 \%$ for $\mathrm{C} 21$ or $50 \%$ for $\mathrm{RC} 21$.

${ }^{5} \mathrm{RC} 21 \_2 \mathrm{yo}, \mathrm{RC} 21 \_3 y o, \mathrm{RC} 21 \_4$ yo $=$ heifers that re-calved within $21 \mathrm{~d}$ of PSC, provided they were reared, for first calvers, second calvers, and third calvers, respectively. 


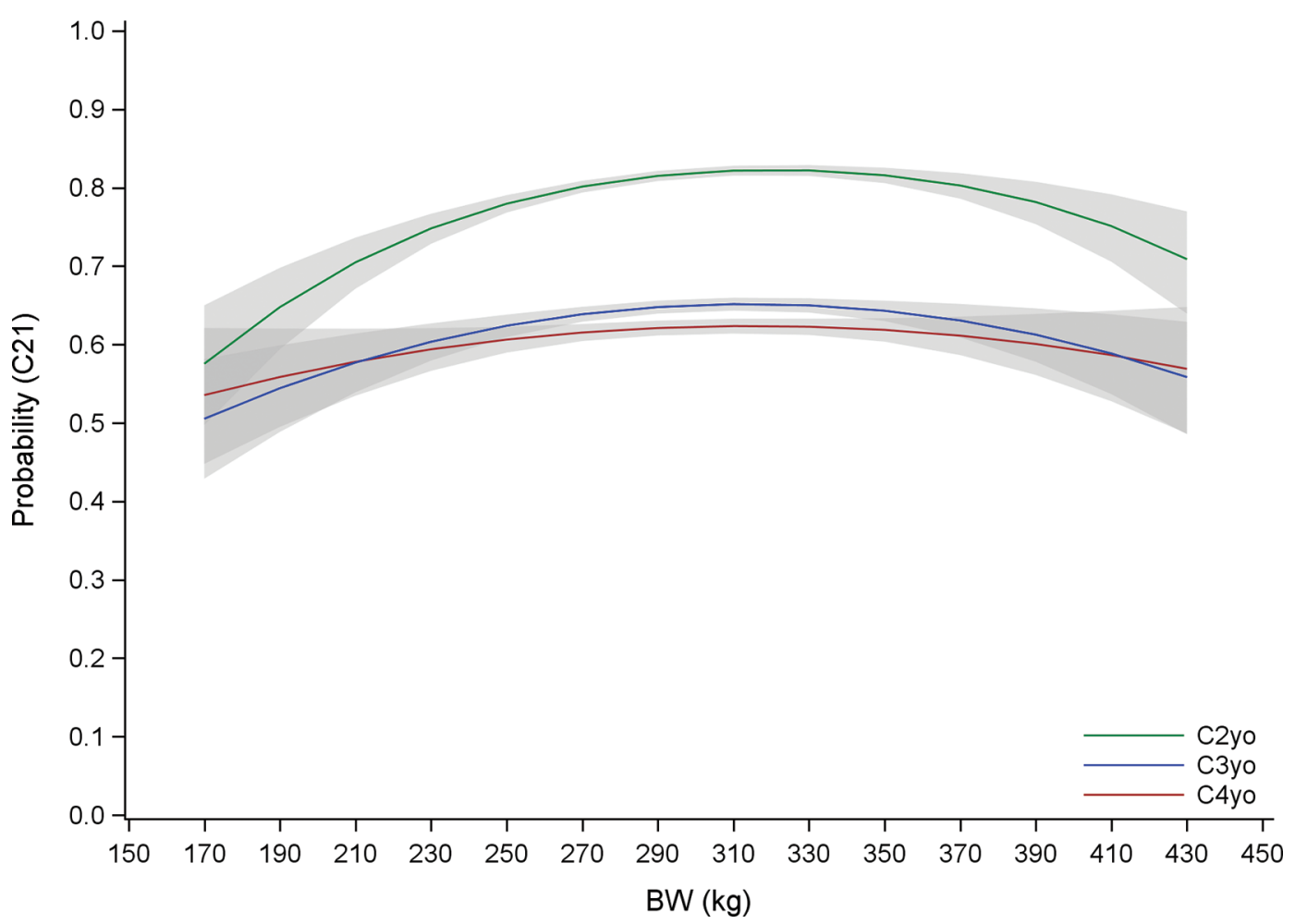

Figure 2. Relationship between BW at 15 mo of age and 21-d calving rate (calved within $21 \mathrm{~d}$ of planned start of calving, provided they calved; C21) for Holstein-Friesian $\times$ Jersey crossbreed (FJ) heifers that calved as 2-yr-olds (C2yo), 3-yr-olds (C3yo), or 4-yr-olds (C4yo). Shaded areas indicate $95 \%$ CI.

(Table 3 ) and for heifers at 6 and 12 mo of age (Supplemental Tables S1 and S2, https://doi.org/10.3168/jds .2019-17545).

\section{DISCUSSION}

This study aimed to explore the relationships between BW of dairy heifers and stayability and reproductive success for first, second, and third calving. Results reported here show significant effects of BW at 6,12 , and 15 mo of age on STAY and the reproductive variables calving rate and re-calving rate. As BW at 6, 12 and 15 mo of age increased, STAY to first, second, and third calving increased up to a maximum, from which further increases in BW did not result in greater STAY. Archbold et al. (2012) reported that a greater proportion of heavier $\mathrm{F}$ heifers were present at the beginning of first (93 vs. $82 \%$ ) and second (76\% vs. $62 \%$ ) lactation compared with lighter heifers. Results from the current study support those reported by Archbold et al. (2012), in that BW had a positive effect on probability of calving in subsequent years for all 5 breed groups studied (F, FX, FJ, JX, and J).

The analysis of reproductive variables is difficult, especially when considering variables such as calving interval, days to calving, and calving rate, because females that did not calve are treated as "missing" in the data set. Treating females that did not calve as missing (i.e., C21) does not consider an important source of variation in fertility (Donoghue et al., 2004), as females that failed to calve in that year also failed to calve early. The current study has considered BW effects on both calving rate (including only cows that calved; $\mathrm{C} 21$ ) and re-calving rate (including cows that were old enough to calve but failed to do so, hence also "failed to calve early," RC21) to provide a thorough analysis of calving pattern. Unsurprisingly, due to the inclusion of heifers that failed to calve in the re-calving data set, we found a greater effect of BW on re-calving rate compared with calving rate, as it was a combination of stayability and calving early. Nevertheless, a large range in BW occurred, in which $\mathrm{C} 21$ and $\mathrm{RC} 21$ were "good," (above the specified thresholds) and this range overlapped. The target C21 for first-calving heifers is $75 \%$ (DairyNZ, 2018); in the analysis presented here, FJ heifers between 231 and $411 \mathrm{~kg}$ at 15 mo of age had a predicted mean 21-d calving rate of $75 \%$ or greater. To the authors' knowledge, no targets exist for 21-d re-calving rates of 15 -mo heifers. For the purposes of this study, an arbitrary target of $70 \%$ was used. The 


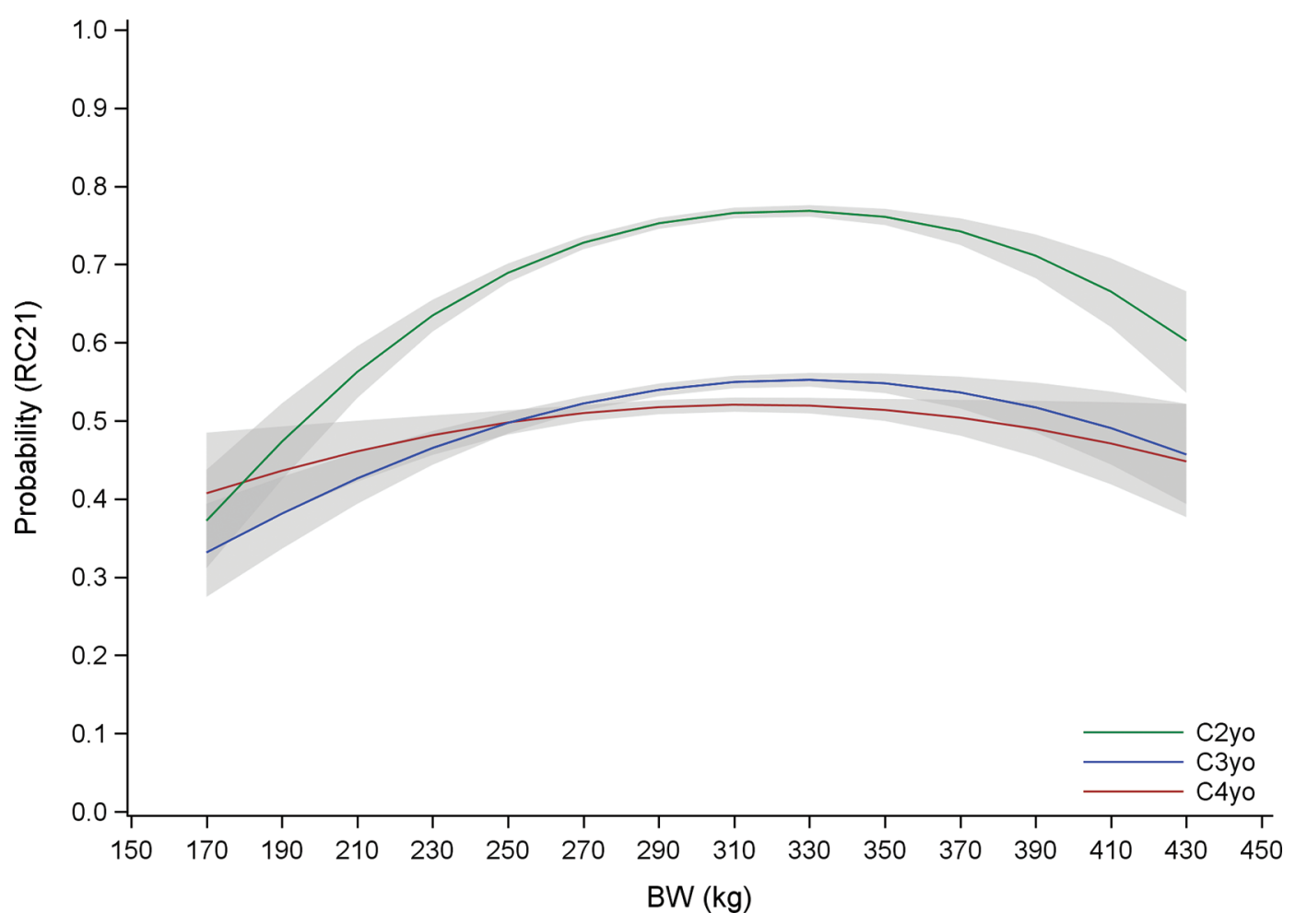

Figure 3. Relationship between BW at 15 mo of age and 21-d re-calving rate (calved within $21 \mathrm{~d}$ of planned start of calving, provided they calved the year prior; RC21) for Holstein-Friesian $\times$ Jersey crossbreed (FJ) heifers that calved as 2-yr-olds (C2yo), 3-yr-olds (C3yo), or 4-yr-olds (C4yo). Shaded areas indicate $95 \%$ CI.

range in 15-mo BW of FJ heifers where re-calving rate exceeded $70 \%$ was between 255 and $396 \mathrm{~kg}$. The mean 15-mo BW of FJ heifers was $301.5 \mathrm{~kg}$ (Handcock et al., $2019)$, indicating a large range $(141 \mathrm{~kg})$ in 15 -mo BW (46.5 $\mathrm{kg}$ below average and $94.5 \mathrm{~kg}$ above average) for which the first calving pattern was good.

Heifers at the heaviest end of the BW range in the current study had a slight decline in reproductive performance compared with heifers in the mid-range of BW. Ferrell (1982) reported that for beef heifers, heifer BCS had a curvilinear relationship with pregnancy rates. Ferrell (1982) determined that a BCS of 6.7 (on a 1 to 9 scale) was optimum for pregnancy rate, and that excessively thin and excessively fat heifers were at risk of having lower pregnancy rates compared with moderately conditioned heifers. Body condition score records were not available for heifers in the current study; however, it is likely that heifers at the very heavy end of the range were in better condition than the lighter heifers, due to the high positive correlation between BW and BCS (Pryce and Harris, 2006; Roche et al., 2007), which may have influenced reproductive performance. In addition, Brickell et al. (2009a) reported that non-pregnant heifers $(\mathrm{n}=16)$ tended to be heavier at 6 mo of age and were significantly heavier than pregnant heifers $(\mathrm{n}=412)$ at 15 mo of age. However, these results should be interpreted with caution due to the low number of non-pregnant heifers spread across 16 dairy farms included in the study by Brickell et al. (2009a).

A previous study, based on the same heifers as the current study, showed that heifers that were heavier produced more milk in first lactation and accumulated over 3 parities than did heifers that were lighter (Handcock et al., 2019). It is well reported that milk production and reproduction are negatively genetically correlated (Grosshans et al., 1997; Berry et al., 2003; Pryce and Harris, 2006), in that the selection of cattle to produce more milk is associated with reduced fertility. This negative genetic correlation may partially explain the lower reproductive performance reported for the heaviest heifers in the current study, as they had the highest milk production.

A New Zealand study of lactating F cows by Roche et al. (2007) demonstrated a curvilinear relationship between BW at PSM and the probability of exhibiting estrus before breeding at PSM. In addition, all of the reproductive measures studied (probability of exhibiting estrus before PSM, being mated within $21 \mathrm{~d}$ of PSM, pregnant to first breeding, or within 21, 42, and $84 \mathrm{~d}$ of PSM) were negatively affected when BW or 
BCS during lactation indicated a more severe or longer duration of negative energy balance (NEB) after calving. The majority of cows enter a state of NEB after calving, and high-yielding cows have a better ability to mobilize fat and muscle to support high milk production and hence are more likely to be in a more severe NEB compared with lower-yielding cows (Wathes et al., 2007). In addition, cows that have higher BCS at calving have more BCS available to mobilize and are also likely to be in a more severe NEB (Wathes et al., 2007). Furthermore, BCS is known to be associated with milk production and NEB. Greater NEB could explain the poor reproductive performance of the heaviest heifers in the current study; however, further investigation into potential causative mechanisms is needed to determine the reasons for decline in calving and re-calving rates at the heaviest end of the BW range.

Breed groups differed in reproductive performance, with crossbreeds (FX, FJ, and JX heifers) generally having better performance than straight breeds ( $\mathrm{F}$ and $\mathrm{J}$ heifers). These results are in agreement with those of $\mathrm{Xu}$ and Burton (2003), who reported that crossbred cows have an approximately $2 \%$ greater 6 -wk pregnancy rate compared with $\mathrm{F}$ and $\mathrm{J}$ cows. In addition, both $\mathrm{F}$ and $\mathrm{J}$ breed groups were similar in 21-d calving rate for first calving. Twenty-one-day calving, and recalving rates were superior for $\mathrm{J}$ cows compared with $\mathrm{F}$ cows for second and third calvings. These results are similar to those reported by Grosshans et al. (1997), who found that first- and second-lactation J cows had better reproductive performance (shorter intervals from PSM to first service and conception, fewer days open, shorter calving interval, and greater proportions conceiving within 21 and $42 \mathrm{~d}$ of PSM) compared with F cows. In addition, $\mathrm{Xu}$ and Burton (1999) reported that 15-mo-old $\mathrm{F}$ heifers had higher conception and pregnancy rates and lower non-pregnancy rates compared with J heifers, and MacMillan (1994) reported that the non-pregnancy rate for $\mathrm{F}$ heifers was $5.4 \%$ compared with $10 \%$ for $\mathrm{J}$ heifers. Results from the current study support those of $\mathrm{Xu}$ and Burton (1999), MacMillan (1994), and Grosshans et al. (1997), which all found that $\mathrm{F}$ heifers were more likely to calve than $\mathrm{J}$ heifers, whereas the reproductive performance of $\mathrm{J}$ cows exceeded that of $\mathrm{F}$ cows for second and third calving.

\section{CONCLUSIONS}

We discovered positive curvilinear relationships between pre-breeding BW and STAY, C21, and RC21 of dairy heifers. Heifers that were heavier at 6,12 , and 15 mo of age were more likely to remain in the herd for first, second, and third calving, and were more likely to calve early for first calving compared with heifers that were lighter, regardless of breed group. For heifers at the heaviest end of the BW range in the current study, we found a slight decline in STAY and reproductive performance compared with heifers in the mid-range of BW. Consequently, for heifers that were above average in BW, the benefit of increasing BW before first breeding would be small and could even result in a slight decline in STAY. For heifers that were below average in BW, considerable benefits for STAY and reproductive performance could be achieved by improving rearing practices to result in heavier heifers throughout the pre-breeding rearing phase.

\section{ACKNOWLEDGMENTS}

The authors acknowledge Katie Carnie for extracting the data provided by the Livestock Improvement Corporation (Hamilton, New Zealand). The first author was funded by Massey University (Palmerston North, New Zealand). The authors have not stated any conflicts of interest.

\section{REFERENCES}

Archbold, H., L. Shalloo, E. Kennedy, K. M. Pierce, and F. Buckley. 2012. Influence of age, body weight and body condition score before mating start date on the pubertal rate of maiden HolsteinFriesian heifers and implications for subsequent cow performance and profitability. Animal 6:1143-1151. https://doi.org/10.1017/ S1751731111002692.

Berry, D. P., F. Buckley, P. Dillon, R. D. Evans, M. Rath, and R. F. Veerkamp. 2003. Genetic relationships among body condition score, body weight, milk yield, and fertility in dairy cows. J. Dairy Sci. 86:2193-2204. https://doi.org/10.3168/jds.S0022 $-0302(03) 73809-0$.

Brickell, J. S., N. Bourne, M. M. McGowan, and D. C. Wathes. 2009a. Effect of growth and development during the rearing period on the subsequent fertility of nulliparous Holstein-Friesian heifers. Theriogenology 72:408-416. https://doi.org/10.1016/j.theriogenology .2009.03.015.

Brickell, J. S., M. M. McGowan, D. U. Pfeiffer, and D. C. Wathes. 2009b. Mortality in Holstein-Friesian calves and replacement heifers, in relation to body weight and IGF-I concentration, on 19 farms in England. Animal 3:1175-1182. https://doi.org/10.1017/ S175173110900456X.

Brickell, J. S., and D. C. Wathes. 2011. A descriptive study of the survival of Holstein-Friesian heifers through to third calving on English dairy farms. J. Dairy Sci. 94:1831-1838. https://doi.org/ 10.3168/jds.2010-3710.

Brownlie, T. S., J. M. Morton, C. Heuer, J. Hunnam, and S. McDougall. 2014. Reproductive performance of seasonal-calving, pasturebased dairy herds in four regions of New Zealand. N. Z. Vet. J. 62:77-86. https://doi.org/10.1080/00480169.2013.848499.

DairyNZ. 2018. Calving pattern. Accessed Nov. 5, 2018. https://www .dairynz.co.nz/animal/reproduction-and-mating/calving-pattern/.

Donoghue, K. A., R. Rekaya, and J. K. Bertrand. 2004. Comparison of methods for handling censored records in beef fertility data: Field data. J. Anim. Sci. 82:357-361. https://doi.org/10.2527/ $2004.822357 \mathrm{x}$

Ferrell, C. L. 1982. Effects of postweaning rate of gain on onset of puberty and productive performance of heifers of different breeds. J. Anim. Sci. 55:1272-1283. https://doi.org/10.2527/jas1982 $.5561272 \mathrm{x}$ 
Fonseca, F. A., J. H. Britt, B. T. McDaniel, J. C. Wilk, and A. H. Rakes. 1983. Reproductive traits of Holsteins and Jerseys. Effects of age, milk yield, and clinical abnormalities on involution of cervix and uterus, ovulation, estrous cycles, detection of estrus, conception rate, and days open. J. Dairy Sci. 66:1128-1147. https://doi .org/10.3168/jds.S0022-0302(83)81910-9.

Gilmour, A. R., B. J. Gogel, B. R. Cullis, S. J. Welham, and R. Thompson. 2015. ASReml User Guide Release 4.1 Structural Specification. VSN International Ltd., Hemel Hempstead, UK.

Grosshans, T., Z. Z. Xu, L. J. Burton, D. L. Johnson, and K. L. Macmillan. 1997. Performance and genetic parameters for fertility of seasonal dairy cows in New Zealand. Livest. Prod. Sci. 51:41-51. https://doi.org/10.1016/S0301-6226(97)00104-8.

Haile-Mariam, M., and J. E. Pryce. 2019. Genetic evaluation of gestation length and its use in managing calving patterns. J. Dairy Sci. 102:476-487. https://doi.org/10.3168/jds.2018-14981.

Handcock, R. C., N. Lopez-Villalobos, L. R. McNaughton, P. J. Back, G. R. Edwards, and R. E. Hickson. 2018. Live weight and growth of Holstein-Friesian, Jersey and crossbred dairy heifers in New Zealand. N. Z. J. Agric. Res. 62:173-183. https://doi.org/10.1080/ 00288233.2018 .1465984$.

Handcock, R. C., N. Lopez-Villalobos, L. R. McNaughton, P. J. Back, G. R. Edwards, and R. E. Hickson. 2019. Positive relationships between body weight of dairy heifers and their first-lactation and accumulated three-parity lactation production. J. Dairy Sci. 102:4577-4589. https://doi.org/10.3168/jds.2018-15229.

Hemming, N., L. R. McNaughton, and C. Couldrey. 2018. Brief communication: Reproductive performance of herds milked once a day all season compared with herds milked twice a day all season. New Zealand Journal of Animal Science and Production 78:170-172.

Hudson, G. F. S., and L. D. Van Vleck. 1981. Relationship between production and stayability in Holstein cattle. J. Dairy Sci. 64:22462250. https://doi.org/10.3168/jds.S0022-0302(81)82836-6.

Kerslake, J. I., P. R. Amer, P. L. O'Neill, S. L. Wong, J. R. Roche, and C. V. C. Phyn. 2018. Economic costs of recorded reasons for cow mortality and culling in a pasture-based dairy industry. J. Dairy Sci. 101:1795-1803. https://doi.org/10.3168/jds.2017-13124.

Livestock Improvement Corporation and DairyNZ. 2018. New Zealand Dairy Statistics 2017-18. Livestock Improvement Corporation, DairyNZ, Hamilton, New Zealand. Dec. 7, 2018. https://www .dairynz.co.nz/publications/dairy-industry/new-zealand-dairy -statistics-2017-18/.

MacMillan, K. L. 1994. Empty heifers. Pages 43-48 in Proc. Ruakura Farmers' Conference. Vol. 46, Ruakura, New Zealand.

McDougall, S., C. Burke, N. B. Williamson, and K. L. MacMillan. 1995. The effect of stocking rate and breed on the period of anoestrum in grazing dairy cattle. Pages $236-238$ in Proc. N.Z. Soc.
Anim. Prod., Dunedin, New Zealand. Vol. 55. http://www.nzsap .org/view/biblio/volume/55.

McDougall, S., and C. Compton. 2006. Reproductive performance in the subsequent lactation of dairy cows previously treated for failure to be detected in oestrus. N. Z. Vet. J. 54:132-140. https://doi .org/10.1080/00480169.2006.36625.

Meier, S., B. Fisher, K. Eketone, L. R. McNaughton, P. R. Amer, P. Beatson, J. R. Bryant, K. G. Dodds, R. J. Spelman, J. R. Roche, and C. R. Burke. 2017. Calf and heifer development and the onset of puberty in dairy cows with divergent genetic merit for fertility. Pages 205-210 in Proc. N.Z. Soc. Anim. Prod., Rotorua, New Zealand. Vol. 77. S. L. Peterson, ed. http://www.nzsap.org/view/ biblio/volume/77.

Pritchard, T., M. Coffey, R. Mrode, and E. Wall. 2013. Understanding the genetics of survival in dairy cows. J. Dairy Sci. 96:3296-3309. https://doi.org/10.3168/jds.2012-6219.

Pryce, J. E., and B. L. Harris. 2006. Genetics of body condition score in New Zealand dairy cows. J. Dairy Sci. 89:4424-4432. https:// doi.org/10.3168/jds.S0022-0302(06)72490-0.

Pryce, J. E., B. L. Harris, and L. R. McNaughton. 2007. The genetic relationship between heifer and cow fertility. Pages 388-391 in Proc. N.Z. Soc. Anim. Prod., Wanaka, New Zealand. Vol. 67. http: //www.nzsap.org/view/biblio/volume/67.

Roche, J. R., K. A. MacDonald, C. R. Burke, J. M. Lee, and D. P. Berry. 2007. Associations among body condition score, body weight, and reproductive performance in seasonal-calving dairy cattle. J. Dairy Sci. 90:376-391. https://doi.org/10.3168/jds.S0022 -0302(07)72639-5

Wathes, D. C., M. Fenwick, Z. Cheng, N. Bourne, S. Llewellyn, D. G. Morris, D. Kenny, J. Murphy, and R. Fitzpatrick. 2007. Influence of negative energy balance on cyclicity and fertility in the high producing dairy cow. Theriogenology 68(Suppl. 1):S232-S241. https://doi.org/10.1016/j.theriogenology.2007.04.006.

Xu, Z. Z., and L. J. Burton. 1999. Reproductive performance of dairy heifers after estrus synchronization and fixed-time artificial insemination. J. Dairy Sci. 82:910-917. https://doi.org/10.3168/jds .S0022-0302(99)75309-9.

Xu, Z. Z., and L. J. Burton. 2003. Reproductive performance of dairy cows in New Zealand: The monitoring fertility report. Page 51. Livestock Improvement Corporation, Hamilton, New Zealand.

\section{ORCIDS}

R. C. Handcock ๑ https://orcid.org/0000-0001-7017-9948

N. Lopez-Villalobos () https://orcid.org/0000-0001-6611-907X 